BIODIK: Jurnal IImiah Pendidikan Biologi
ISSN 2580-0922 (online), ISSN 2460-2612 (print)
Volume 7, Nomor 01, Tahun 2021, Hal. 13-22
Available online at:
https://online-journal.unja.ac.id/biodik

Research Article

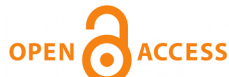

\title{
Pengembangan Ensiklopedia Tumbuhan Obat Masyarakat Kerinci Sebagai Sumber Belajar Materi Keanekaragaman Hayati Untuk Siswa SMA
}

\section{(Development of Encyclopedia of Medicinal Plants for the Kerinci Community as Learning Resources for Biodiversity Materials for High School Students)}

Reni Julianti, Revis Asra, Upik Yelianti

Magister Pendidikan IPA, Pascasarjana, Universitas Jambi

JI. Raden Mattaher No.21, Ps. Jambi, Kota Jambi, Jambi 36133, Indonesia

Corresponding Author: reni.julianti2016@gmail.com

\begin{tabular}{|c|c|}
\hline Informasi Artikel & ABSTRACT \\
\hline $\begin{array}{l}\text { Submit: } 11-12-2020 \\
\text { Diterima: } 24-02-2021 \\
\text { Dipublikasikan: } 12-03-2021\end{array}$ & $\begin{array}{l}\text { The abundant population of plant species in Kerinci district is utilized by the } \\
\text { community for daily needs, including using plants as medicine to cure various } \\
\text { diseases. To help increase public knowledge, especially students, about medicinal } \\
\text { plants, one of them is by integrating into Biology learning in Biodiversity material. This } \\
\text { research is a development research. The development model in this study is the } \\
\text { ADDIE model. The ADDIE model consists of } 5 \text { stages, namely analysis, design, } \\
\text { development, implementation and evaluation. The products of the Kerinci Community } \\
\text { Medicinal Plant Encyclopedia were previously tested and validated by a team of } \\
\text { experts, namely material experts and media experts to determine the feasibility of the } \\
\text { products being made. The Kerinci Community Medicinal Plant Encyclopedia was } \\
\text { validated by media experts with a very good score of } 94.4 \% \text { and material experts with } \\
\text { a score of } 95.46 \% \text { in the very good category. Thus the encyclopedia product is said } \\
\text { to be feasible. This product was then tested at SMAN } 2 \text { Kerinci, the trial was carried } \\
\text { out on } 2 \text { biology subject teachers, a small group consisting of } 9 \text { students, in a large } \\
\text { group consisting of } 34 \text { students. The test results on the teacher obtained a score of } \\
99.2 \% \text {. The test results in the small group obtained a score of } 94.96 \% \text { which was in } \\
\text { the very good category. In the large group trial obtained a score of } 96.44 \% \text { including } \\
\text { the very good category. Thus the product of the Kerinci Community Medicinal Plants } \\
\text { encyclopedia is suitable for use as a learning resource. The effectiveness test of } \\
\text { using the Kerinci Community Medicinal Plant encyclopedia is effective for improving } \\
\text { student learning outcomes. } \\
\text { Key words: Encyclopedia, Medicinal Plants, Biodiversity, ADDIE }\end{array}$ \\
\hline Penerbit & ABSTRAK \\
\hline $\begin{array}{l}\text { Program Studi Pendidikan } \\
\text { Biologi, Fakultas Keguruan dan } \\
\text { IImu Pendidikan, Universitas } \\
\text { Jambi }\end{array}$ & $\begin{array}{l}\text { Melimpahnya populasi jenis tumbuhan yang ada di kabupaten Kerinci dimanfaatkan } \\
\text { masyarakat untuk keperluan sehari-hari, diantaranya memanfaatkan tumbuhan } \\
\text { sebagai obat untuk menyembuhkan berbagai penyakit. Untuk membantu } \\
\text { meningkatkan pengetahuan masyarakat khususnya para peserta didik terhadap } \\
\text { tumbuhan obat salah satunya dengan mengintegrasikan kedalam pembelajaran } \\
\text { Biologi pada materi Keanekaragaman Hayati. Penelitian ini merupakan penelitian } \\
\text { pengembangan. Model pengembangan dalam penelitian ini adalah model ADDIE. } \\
\text { Model ADDIE terdiri dari } 5 \text { tahap yaitu analysis, design, development, implementation } \\
\text { dan evaluation. Produk Ensiklopedia Tumbuhan Obat masyarakat Kerinci } \\
\text { sebelumnya diujicobakan terlebih dahulu divalidasi oleh tim ahli yaitu ahli materi dan } \\
\text { ahli media untuk mengetahui kelayakan dari produk yang dibuat. Ensiklopedia } \\
\text { Tumbuhan Obat Masyarakat Kerinci divalidasi oleh ahli media dengan perolehan } \\
\text { skor } 94,4 \% \text { kategori sangat baik dan ahli materi dengan skor } 95,46 \% \text { kategori sangat } \\
\text { baik. Dengan demikian produk ensiklopedia dikatakan layak. Produk ini kemudian } \\
\text { diujicobakan di SMAN } 2 \text { Kerinci, uji coba dilakukan pada } 2 \text { orang guru mata pelajaran } \\
\text { biologi, kelompok kecil terdiri dari } 9 \text { orang siswa, pada kelompok besar terdiri dari } 34 \\
\text { orang siswa. Hasil uji coba pada guru memperoleh skor } 99,2 \% \text { hasil uji coba pada }\end{array}$ \\
\hline
\end{tabular}


kelompok kecil memperoleh skor 94,96\% yang termasuk kategori sangat baik. Pada uji coba kelompok besar memperoleh skor $96,44 \%$ termasuk kategori sangat baik Dengan demikian produk ensiklopedia Tumbuhan Obat Masyarakat Kerinci ini layak digunakan sebagai sumber belajar. Uji efektifitas penggunaan ensiklopedia Tumbuhan Obat Masyarakat Kerinci efektif untuk meningkatkan hasil belajar siswa.

Kata Kunci: Ensiklopedia, Tumbuhan Obat, Keanekaragaman Hayati, ADDIE

This BIODIK : Jurnal IImiah Pendidikan Biologi is licensed under a CC BY-NC-SA (Creative Commons Attribution-ShareAlike 4.0 International License)

\section{PENDAHULUAN}

Kabupaten Kerinci merupakan salah satu kabupaten yang berada di Provinsi Jambi. Kabupaten Kerinci dikenal sebagai daerah dengan kekayaan makhluk hidup yang tinggi. Kekayaan alam yang dimiliki oleh Kabupaten Kerinci bukan hanya fauna saja namun juga kaya akan floranya. Kekayaan flora yang ada di kabupaten Kerinci tersebar diberbagai wilayah. Terdapat beberapa tumbuhan endemik diantaranya bunga raflesia (Rafflesia arnoldi), bunga bangkai raksasa (Amorphophallus titanium), Kantong semar/kantong beruk (Nephentes sp), pinus strain kerinci (Pinus merkusii strain kerinci), mersawa (Anisoptera sp) serta kayu pacet (Harpullia arborea (Blanco) Radlk).

Melimpahnya populasi jenis tumbuhan yang ada di kabupaten Kerinci dimanfaatkan masyarakat setempat untuk keperluan sehari-hari, yang meliputi: pangan, minuman, pakan ternak/satwa liar, bahan bangunan, tanaman hias, kayu bakar, upacara adat, pewarna, pengahasil tali anyaman dan kerajinan. Namun bukan hanya itu saja, masyarakat Kerinci juga memanfaatkan tumbuhan sebagai obat untuk menyembuhkan berbagai penyakit. Masyarakat Kerinci pada umumnya masih percaya bahwa berbagai jenis tumbuhan memiliki potensi dapat menyembuhkan penyakit. Namun, dengan kemajuan zaman saat ini membuat masyarakat Kerinci perlahan mulai meninggalkan obat tradisional dan beralih ke penggunaan obat kimia. Akibatnya, masyarakat khususnya para remaja tidak mengetahui lagi jenis-jenis tumbuhan yang bisa dijadikan obat. Untuk membantu meningkatkan pengetahuan masyarakat khususnya para peserta didik terhadap tumbuhan obat sebenarnya tidaklah sulit. Apalagi melihat potensi SDA yang dimiliki terutama tingginya keanekaragaman jenis tumbuhan yang ada di Kerinci sebenarnya dapat dijadikan peluang untuk diintegrasikan kedalam pendidikan. Salah satunya dengan mengintegrasikan kedalam pembelajaran Biologi pada materi Keanekaragaman Hayati. Melalui materi Keanekaragaman Hayati tersebut guru bisa memberikan sumber belajar tambahan kepada peserta didik tentang pemanfaatan tumbuhan sebagai obat. Selain itu, guru juga dapat menanamkan sikap peduli terhadap kelestarian jenis keanekaragaman hayati kepada peserta didik.

Materi Keanekaragaman Hayati yang diajarkan di sekolah memuat materi Tingkatan Keanekaragaman Hayati, sebaran keanekaragaman hayati di permukaan bumi, keanekaragaman hayati Indonesia serta ancaman serta usaha pelestarian keanekaragaman hayati, khususnya tentang manfaat keanekaragaman hayati yang digunakan sebagai obat-obatan. Keterbatasan sumber belajar menjadi salah satu faktor kurang maksimalnya peserta didik memahami materi tersebut. ketersediaan media pembelajaran masih sangat terbatas hanya menggunakan buku teks saja. Secara klasikal siswa sudah mendapatkan hasil belajar yang memenuhi KKM. Akan tetapi, masih ada siswa yang belum mendapatkan hasil belajar yang memenuhi nilai KKM.

Bila hal ini terus menerus dibiarkan dan tidak ada tindak lanjut, mungkin kedepannya peserta didik akan mengalami hal yang sama. Untuk membantu mengatasi masalah yang dialami pesera didik 
maka diberikan tambahan sumber belajar pada peserta didik. Penggunaan ensiklopedia merupakan salah satu sumber belajar yang bisa digunakan. Menurut Kamus Besar Bahasa Indonesia edisi kelima (KBBI V) ensiklopedia adalah sebuah karya rujukan yang disusun sedemikian kompleks yang didalamnya mengandung berbagai informasi suatu bidang ilmu pengetahuan, ensiklopedia ini biasanya disusun menurut abjad atau tema. Selain itu, ensiklopedia juga dikenal sebagai suatau daftar subyek yang disertai keterangan-keterangan tentang defenisi.

Penelitian tentang pengembangan ensiklopedia tumbuhan obat masih sedikit dilakukan. Padahal ensiklopedia menurut Hidayat., dkk (2015:55) bila digunakan dalam proses pembelajaran dapat meningkatkan hasil belajar peserta didik terutama dilihat dari hasil pretest dan posttest. Selain dapat meningkatkan hasil belajar, pengggunaan ensiklopedia dapat memberikan warna baru dalam kegiatan pembelajaran serta membantu siswa memahami materi yang disampaikan guru karena pada umumnya ensiklopedia menggabungkan teks dengan gambar yang dikolaborasikan sedemikian rupa sehingga menarik.

Penelitian yang berkaitan dengan tumbuhan obat kebanyakan dilakukan oleh mahasiswa biologi murni yang meneliti etnobotani tumbuhan obat, diantaranya yang terdapat di desa Tabun kecamatan VII koto kabupaten Tebo Jambi oleh Indriati (2014), di Taman Nasional Bukit Duabelas Kabupaten Sarolangun Jambi oleh Andhika., dkk (2015), di Kecamatan Kunto Darussalam Kabupaten Rokan Hulu oleh Aeni., dkk (2016), di suku dani kabupaten Jayawijaya Papua oleh Mabel., dkk (2016), serta yang terdapat di Hutan Adat Hiang Kabupaten Kerinci Jambi oleh Andesmora., dkk (2017). Namun, hasil penelitian tersebut tidak dibuat dalam bentuk media pembelajaran seperti halnya ensiklopedia tumbuhan obat. Dengan demikian sangat perlu dilakukan penelitian tentang pengembangan ensiklopedia tumbuhan obat. Apalagi hasil penelitian sebelumnya menunjukkan bahwa penggunaan ensiklopedia dapat meningkatkan dan menambah pengetahuan.

\section{METODE PENELITIAN}

Penelitian ini merupakan penelitian dan pengembangan (Research and Development). Model pengembangan yang digunakan dalam penelitian ini adalah model ADDIE yang dikembangkan oleh Lee dan Owen (2004). Model pengembangan ADDIE memiliki 5 tahap yaitu Analysis, Design, Development, Implementation dan Evaluation.

\section{Analisis (Analysis)}

Pada tahap analisis dilakukan identifikasi penyebab permasalahan yang terjadi dalam pembelajaran. Pada tahap ini juga dilakukan identifikasi apakah media benar-benar dibutuhkan oleh siswa.

\section{Desain (Design)}

Tahap desain terdiri dari penentuan tim pengembang, penentuan jadwal pembuatan ensiklopedia, menentukan cakupan materi, spesifikasi produk media ensiklopedia, pembuatan storyboard dan menyiapkan sumber daya yang diperlukan.

\section{Tahap Pengembangan (Develop)}

Pengembangan adalah tahapan membuat desain yang telah dibuat sebelumnya menjadi sebuah produk yang utuh. Sebelum produk dibuat, terlebih dahulu menentukan indikator kemudian dilakukan pengambilan sampel tumbuhan obat dan diidentifikasi jenisnya. 


\section{Implementasi (Implementation)}

Implementasi adalah tahapan nyata yang dilakukan setelah proses pengembangan selesai. Pada tahapan ini produk yang telah dikembangkan diujicobakan kepada siswa dan diberi angket penilaian terhadap produk. Ujicoba produk penelitian ini dilakukan pada guru mata pelajaran Biologi, kelompok kecil dan kelompok besar. Tahap implementasi juga dilakukan uji efektiftas berdasakan data hasil belajar siswa sebelum dan sesudah menggunakan produk.

\section{Evaluasi (Evaluation)}

Setelah produk diujicoba maka tahapan selanjutnya adalah tahapan evaluasi. Tahap ini kegiatan yang dilakukan untuk melihat produk yang dikembangkan sudah berhasil atau tidak digunakan.

Penelitian pengembangan ini dilakukan pada Semester Ganjil Tahun Ajaran 2020/2021. Lokasi penelitian dan uji coba produk dilakukan di SMA Negeri 2 Kerinci. Subjek uji coba produk dalam penelitian ini terdiri dari peserta didik SMA Negeri 2 Kerinci di kelas X MIPA sebanyak 9 orang sebagai subjek uji coba kelompok kecil, 34 siswa sebagai subjek ujicoba kelompok besar dan 2 orang guru mata pelajaran biologi. Instrumen pengumpulan data dalam penelitian pengembangan ini adalah berupa angket (kuisioner), wawancara dan pengambilan sampel di lapangan. Angket yang digunakan dalam mengumpulkan data adalah angket uji kelayakan media dan materi, angket respon guru dan respon peserta didik.

\section{HASIL PENELITIAN DAN PEMBAHASAN}

\section{Penyajian Hasil Pengembangan}

Ensiklopedia Tumbuhan Obat Masyarakat Kerinci Sebagai Sumber Belajar Materi Keanekaragaman Hayati untuk Siswa SMA telah melalui serangkaian tahapan dari model pengembangan ADDIE. Hasil yang diperoleh berupa penilaian dari validator media terhadap desain ensiklopedia. Kemudian penilaian dari validator materi terhadap isi ensiklopedia, persepsi dan respon siswa terhadap penggunaan ensiklopedia, serta persepsi guru mata pelajaran Biologi.

\section{Hasil Validasi Ahli Media}

Ensiklopedia Tumbuhan Obat Masyarakat Kerinci Sebagai Sumber Belajar Materi Keanekaragaman Hayati untuk Siswa SMA yang telah selesai dibuat, kemudian divalidasi oleh validator media. Proses validasi ini dilakukan sebanyak dua kali. Dari hasil validasi tersebut diperoleh saran dan perbaikan. Adapun hasil validasi tahap pertama diperoleh persentase $73,61 \%$ dengan kategori baik, kemudian hasil validasi kedua diperoleh persentase $94,4 \%$ kriteria sangat baik.

Tabel 1. Hasil validasi ahli media

\begin{tabular}{lccc}
\hline \multicolumn{1}{c}{ Aspek } & Skor & Persentase (\%) & Katergori \\
\hline Desain grafis & 52 & 91,6 & Sangat Baik \\
Desain isi/konten & 31 & 100 & Sangat Baik \\
Total & 83 & 94,4 & Sangat Baik \\
\hline
\end{tabular}

Berdasarkan tabel.1 diketahui bahwa terdapat dua aspek yang dinilai kelayakannya pada validasi media yaitu desain grafis dan desain isi/konten. Aspek desain grafis terdiri dari 12 item 
pertanyaan. Nilai kelayakan pada aspek desain grafis yaitu $91,6 \%$ dan termasuk kategori sangat baik. Pada aspek desain dinyatakan sangat baik dengan nilai persentase 100\%. Dengan demikian secara umum penilaian yang diberikan oleh validator media terhadap ensiklopedia tumbuhan obat masyarakat Kerinci termasuk kedalam kategori sangat baik atau sangat layak. Sehingga dapat dinyatakan layak umtuk dijadikan sebagai sumber belajar.

Sumber belajar yang didesain dalam bentuk ensiklopedia tumbuhan obat masyarakat Kerinci memiliki keunggulan seperti penggunaannya yang sangat praktis. Hal ini sesuai dengan pendapat Hidayat., dkk (2015:48) salah satu sumber belajar adalah media pembelajaran dalam bentuk cetak memiliki kelebihan salah satunya media tersebut dapat dipelajari kapan dan dimana saja karena mudah dibawa. Diperkuat lagi oleh penelitian Nizar., dkk (2017:12) bahwa sumber belajar berbasis cetak menampilkan teks dan visual yang statis sehingga memudahkan siswa dalam pengamatan ciri morfologi tanaman obat.

\section{Hasil Validasi Ahli Materi}

Ensiklopedia Tumbuhan Obat Masyarakat Kerinci Sebagai Sumber Belajar Materi Keanekaragaman Hayati untuk Siswa SMA yang telah selesai dibuat, kemudian divalidasi oleh ahli materi. Validasi materi ini bertujuan untuk menilai kelayakan materi yang terdapat di ndalam ensiklopedia. Proses validasi ini dilakukan sebanyak tiga kali. Dari hasil validasi tersebut diperoleh saran dan perbaikan. Validasi tahap pertama didapatkan persentase kelayakan $71,6 \%$ dengan kategori baik. Validasi kedua didapatkan nilai persentase $79,54 \%$ dengan kategori baik. Namun, masih ada beberapa perbaikan yang harus dilakukan terutama pada bagian kata pengantar, deskripsi morfologi dan cara konsumsi. Setelah direvisi, pada validasi ketiga didapatkan nilai persentase kelayakan 95,46\% dengan kategori sangat baik sehingga materi ensiklopedia tumbuhan obat masyarakat Kerinci sudah layak untuk diujicobakan tanpa ada revisi.

Tabel 2. Hasil validasi ahli materi

\begin{tabular}{lccc}
\hline \multicolumn{1}{c}{ Aspek } & Skor & Persentase (\%) & Katergori \\
\hline Desain grafis & 64 & 92,85 & Sangat Baik \\
Desain isi/konten & 20 & 100 & Sangat Baik \\
Total & 84 & 95,46 & Sangat Baik \\
\hline
\end{tabular}

Berdasarkan tabel.2 diketahui bahwa terdapat dua aspek yang dinilai kelayakannya pada validasi materi yaitu konstruk isi/konten dan grafika. Aspek konstruk isi/konten terdiri dari 14 item pertanyaan. Nilai kelayakan pada aspek konstruk isi/konten yaitu 92,85\% dan termasuk kategori sangat baik. Selanjutnya pada aspek grafika terdiri dari 8 item pertanyaan, yaitu dari nomor 15-22. Secara umum aspek grafika dinyatakan sangat baik dengan nilai persentase $100 \%$. Dengan demikian secara keseluruhan materi yang terdapat pada ensiklopedia tumbuhan obat masyarakat Kerinci sudah layak dijadikan sebagai sumber belajar. 


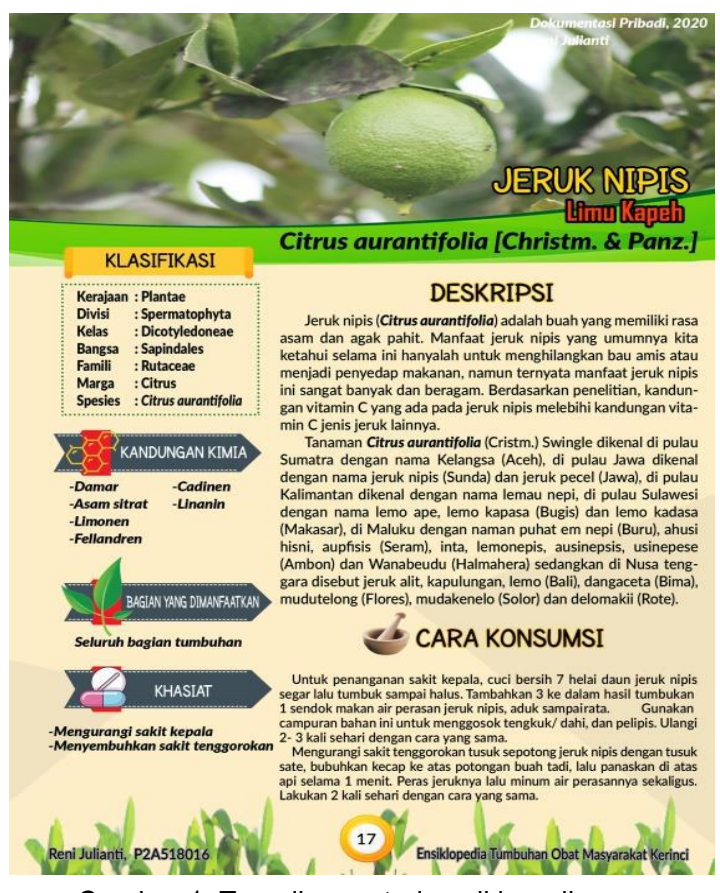

Gambar 1. Tampilan materi ensiklopedia

\section{Hasil Ujicoba Produk}

Ensiklopedia Tumbuhan Obat Masyarakat Kerinci Sebagai Sumber Belajar Materi Keanekaragaman Hayati untuk Siswa SMA yang telah dikembangkan dan dianggap layak oleh tim ahli kemudian diujicobakan pada subjek ujicoba. Subjek ujicoba yang digunakan adalah Siswa SMA Negeri 2 Kerinci Kelas X MIPA1. Ujicoba ini dilakukan pada kelompok kecil dan besar. Serta guru mata pelajaran Biologi.

Tabel 3. Hasil respon guru

\begin{tabular}{lccc}
\hline \multicolumn{1}{c}{ Aspek } & Skor & Persentase (\%) & Katergori \\
\hline Tampilan Media & 71 & 98,61 & Sangat Baik \\
Kemudahan Penggunaan & 24 & 100 & Sangat Baik \\
Kejelasan Bahasa & 32 & 100 & Sangat Baik \\
Total & 127 & 99,21 & Sangat Baik \\
\hline
\end{tabular}

Dua orang guru mata pelajaran Biologi di kelas X SMA Negeri 2 Kerinci diminta responnya terhadap Ensiklopedia Tumbuhan Obat Masyarakat Kerinci Sebagai Sumber Belajar Materi Keanekaragaman Hayati Hasil angket respon guru berdasarkan Tabel 3. menunjukkan bahwa ensiklopedia sangat baik dengan nilai persentase 99,21\%. Penilaian pada aspek tampilan media memperoleh nilai persentase $98,61 \%$ dengan kategori sangat baik, aspek kemudahan penggunaan memperoleh nilai $100 \%$ dengan kategori sangat baik serta pada aspek kejelasan bahasa/konten memperoleh nilai persentase $100 \%$. secara keseluruhan ensiklopedia tumbuhan obat masyarakat Kerinci mendapatkan respon yang sangat baik.

Tabel 4. Hasil respon ujicoba siswa kelompok kecil

\begin{tabular}{lccc}
\hline \multicolumn{1}{c}{ Aspek } & Skor & Persentase (\%) & Katergori \\
\hline Tampilan Media & 271 & 94,09 & Sangat Baik \\
Kemudahan Penggunaan & 102 & 94,44 & Sangat Baik \\
Kejelasan Bahasa & 139 & 96,51 & Sangat Baik \\
Motivasi & 35 & 97,22 & Sangat Baik \\
Total & 547 & 94,96 & Sangat Baik \\
\hline
\end{tabular}


Berdasarkan Tabel.4 ujicoba pada kelompok kecil diketahui bahwa ensiklopedia tumbuhan obat masyarakat Kerinci berada pada kategori sangat baik dengan nilai persentase 94,96\%. Hasil penilaian pada aspek tampilan ensiklopedia memperoleh nilai persentase $94,09 \%$ dengan kategori sangat baik, aspek kemudahan penggunaan memperoleh nilai $94,44 \%$ dengan kategori sangat baik, aspek kejelasan bahasa/konten memperoleh persentase $96,5 \%$ serta pada aspek motivasi memperoleh nilai persentase $97,22 \%$.

Tabel 5. Hasil respon ujicoba siswa kelompok besar

\begin{tabular}{lccc}
\hline \multicolumn{1}{c}{ Aspek } & Skor & Persentase $(\%)$ & Katergori \\
\hline Tampilan Media & 765 & 95,62 & Sangat Baik \\
Kemudahan Penggunaan & 290 & 77,58 & Sangat Baik \\
Kejelasan Bahasa & 390 & 97,5 & Sangat Baik \\
Motivasi & 99 & 99 & Sangat Baik \\
Total & 1543 & 96,44 & Sangat Baik \\
\hline
\end{tabular}

Pada uji coba kelompok besar melibatkan 25 orang siswa SMA Negeri 2 Kerinci. Hasil respon siswa terhadap ensiklopedia tumbuhan obat masyarakat Kerinci berada pada kategori sangat baik dengan nilai persentase $96,44 \%$. Hasil penilaian pada aspek tampilan ensiklopedia memperoleh nilai persentase $95,62 \%$. Hal ini dikarenakan komponen tampilan ensiklopedia tumbuhan obat masyarakat Kerinci ini di buat dengan desain yang simpel dan menarik dengan kombinasi warna yang padu. Menurut Wijarini dan Zulfadli (2018:14) bahwa pemilihan warna yang menarik (full colour) dapat menarik perhatian siswa dan dapat meningkatkan minat baca.

Pada aspek aspek kemudahan penggunaan memperoleh nilai persentase $77,58 \%$ dengan kategori sangat baik. Hal ini dikarenakan ensiklopedia di buat dalam bentuk buku sehingga dapat digunakan dengan mudah dan tidak membutuhkan prosedur yang rumit. Hal ini sesuai dengan pendapat Wati (2016:26) bahwa buku merupakan media yang praktis digunakan di dalam pembelajaran. Diperkuat lagi oleh pendapat Ashyar (2012:57) bahwa media pembelajaran dalam bentuk cetak (buku) dapat dipelajari atau digunakan kapan saja dan dimana saja.

Selain itu penyajian materi pada ensiklopedia tumbuhan obat masyarakat Kerinci ini dapat membantu siswa karena disajikan secara lengkap, mendalam, menarik terutama dalam menjelaskan karakteristik tumbuhan serta penggunaan tumbuhan dalam pengobatan. Hal ini sejalan dengan hasil penelitian Suwarni (2015) bahwa penyajian materi tumbuhan obat lokal di dalam ensiklopedia dapat memberikan informasi terkait potensi tumbuhan yang ada di lingkungan sekitar yang dapat dijadikan sebagai obat. Selain itu penggunaan gambar dan warna yang menarik dapat menjadi solusi untuk mengurangi efek kebosanan. Hal ini sejalan dengan pendapat Hidayat, dkk (2015:48) bahwa penggunaan gambar bila dikaitkan dengan pembelajaran dapat membuat sesuatu menjadi nyata sehingga konsep yang dipelajari menjadi lebih nyata.

Selanjutnya, pada aspek kejelasan bahasa/konten memperoleh nilai persentase 97,5\%. Hal ini dikarenakan ensiklopedia tumbuhan obat masyarakat Kerinci ini menggunakan bahasa dan kalimat yang dimudah dimengerti dan dipahami. Hal ini sesuai dengan pendapat Atmaji, dkk (2019:101) bahwa dalam ensikklopedia sebaiknya digunakan bahasa yang formal dan gaya bahasa yang baik. Selain itu penjelasannya yang detil dan tidak berbelit-belit teruatama dalam menjelaskan cara penggunaan tumbuhan untuk dijadikan sebabagai obat. Kemudian pada aspek motivasi memperoleh nilai persentase 99\% dengan kriteria sangat baik. Hal ini dikarenakan bahasa yang digunakan dapat membangkitkan motivasi siswa dalam menjaga dan memanfaatkan tumbuhan sebagai bahan baku obat. 


\section{Hasil uji Efektifitas}

Data hasil belajar siswa baik yang pretes maupun postes dapat dilihat pada tabel 6 . Perolehan data rata-rata hasil belajar pre test sebesar 66,15 dengan kategori belum tuntas sedangkan perolehan data rata-rata hasil belajar post test sebesar 78,97 dengan kategori tuntas.

Tabel 6. Hasil belajar siswa

\begin{tabular}{ccc}
\hline Nilai & Rata-rata & Katergori \\
\hline Pre test & 66,15 & Belum tuntas \\
Post test & 78,97 & Tuntas \\
\hline
\end{tabular}

Dengan demikian dapat disimpulkan bahwa penggunaan ensiklopedia tumbuhan obat masyarakat Kerinci memberikan pengaruh terhadap peningkatan pre test ke post test. Dengan kata lain penggunaan ensiklopedia tumbuhan obat masyarakat Kerinci sangat efektif untuk meningkatkan hasil belajar siswa.

Tabel 7. Hasil uji normalitas Shapiro-Wilk

\begin{tabular}{cccc}
\hline Nilai & Statistic & Df & Sig. \\
\hline Pre test &, 941 & 34 &, 066 \\
Post test &, 955 & 34 &, 172 \\
\hline
\end{tabular}

Hasil uji normalitas data nilai pretes dan postes didapatkan berdistribusi normal dengan nilai signifikansi (sig) Shapiro-Wilk yang didapatkan lebih besar 0,05. Sehingga dapat disimpulkan varians nilai pretes dan postes adalah sama atau homogen. Dengan demikian syarat mutlak untuk uji independen $\mathrm{t}$ tes terpenuhi dan dapat dilakukan.

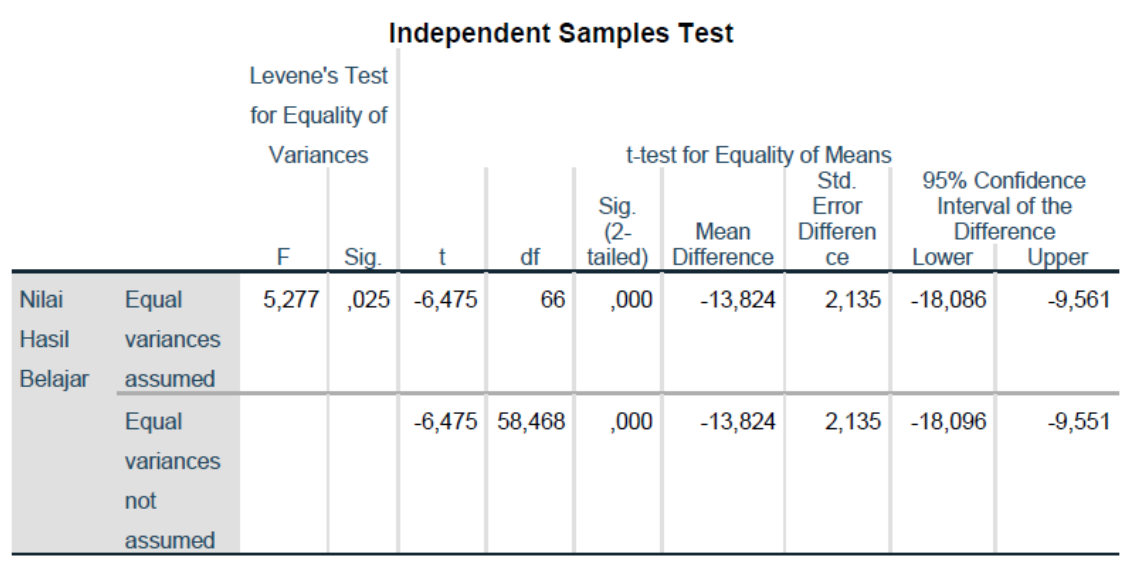

Hasil uji independent samples $\mathrm{t}$ test diperoleh nilai sig (2-tailed) sebesar $0,000<0,05$, maka $\mathrm{HO}$ ditolak dan $\mathrm{H} 1$ diterima. Sehingga dapat disimpulkan bahwa ada perbedaan rata-rata yang signifikan antara hasil belajar postes dan pretes, artinya ada pengaruh penggunaan ensiklopedia tumbuhan obat 
masyarakat Kerinci berbasis terhadap hasil belajar siswa. Hal ini sejalan dengan penelitian Faridah., dkk (2014:587) bahwa penggunaan ensiklopedia sebagai sumber belajar dapat meningkatkan hasil belajar siswa. Selain itu diperkuat oleh hasil penelitian Hidayat., dkk (2015:53) ensiklopedia dapat meningkatkan hasil belajar siswa tanpa membedakan tingkat kemampuan tinggi maupun sedang.

Adanya perbedaan rata-rata hasil belajar siswa antara pretes dan postes disebabkan karena siswa mendapatkan informasi yang banyak mengenai materi yang dipelajari ketika menggunakan ensiklopedia. Ensiklopedia tumbuhan obat masyarakat kerinci banyak memberikan informasi yang berkaitan tentang keanekaragaman hayati terutama pada tumbuhan yang dapat dimanfaatkan sebagai obat. Hal ini sesuai dengan pendapat Anwas (2016:18) bahwa buku (ensiklopedia tumbuhan obat masyrakat Kerinci) ini dapat menyajikan pesan/informasi dalam jumlah yang cukup banyak. Menurut Yelianti, U., Kusuma, L., \& Intan, A. (2020) bahwa bahan ajar yang menggunakan tumbuhan lokal atau disekitar peserta didik akan dapat meningkatkan motivasi dan hasil belajar.

\section{KESIMPULAN}

Berdasarkan hasil penelitian dan pengembangan Ensiklopedia tumbuhan obat masyarakat Kerinci dikembangkan dengan menggunakan model pengembangan ADDIE yang terdiri dari 5 langkah yakni: Analysis, Design, Develop, Implementation dan Evaluation. telah berhasil melewati tahap validasi dari para ahli media dan ahli materi Ensiklopedia tumbuhan obat masyarakat Kerinci divalidasi oleh ahli media dan ahli materi dengan hasil sangat baik. Hasil Respon guru terhadap Ensiklopedia tumbuhan obat masyarakat Kerinci berada pada kategori sangat baik. Hasil Respon siswa terhadap Ensiklopedia tumbuhan obat masyarakat Kerinci pada ujicoba kelompok kecil dan kelompok besar berada pada kategori sangat baik. Ensiklopedia tumbuhan obat masyarakat Kerinci ditinjau dari rata-rata hasil belajar postes lebih baik dibandingkan hasil belajar pretest.

\section{UCAPAN TERIMA KASIH}

Penulis mengucapkan terimaksih kepada dosen pembimbing yang telah memberikan bimbingan dan arahan kepada penulis untuk memperbaiki jurnal ini. terimaksih kepada rekan-rekan seperjuangan yang telah memberikan motivasi dan saran dalam penyelesain jurnal ini.

\section{DAFTAR PUSTAKA}

Aeni, N., Purnama, A.N., Afifah, N. 2016. Identifikasi Tumbuhan Obat Di Kecamatan Kunto Darussalam Kabupaten Rokan Hulu. Universitas Pasir Pengaraian.

Andesmora, E.V., Muhadiono, and Hilwan, I. 2017. Etnobotanical Study of Plants Used by People in Hiang Indigenous Forest Kerinci, Jambi. 7 (2), 95-101.

Andhika, R.R., Hariyadi, B., dan Saudagar, F. 2015. Etnobotani Penghasil Getah oleh Suku Anak Dalam di Tanam Nasional Bukit Duabelas Kabupaten Sarolangu, jambi. Jurnal IImu Pertanian Indonesia (JIPI). 20(1): 33-38.

Anwas, O.M. (2016). Model Buku Teks Pelajaran Berbasis Teknologi. Informasi dan Komunikasi Kwangsan. 4(1): 17-32.

Asyhar, Rayandra. (2012). Kreatif Mengembangkan Media Pembelajaran. Jakarta: Referensi Jakarta. Departemen Pendidikan dan Kebudayaan. 2016. Kamus Besar Bahasa Indonesia Edisi Kelima (KBBI V) Android. 
Faridah, L.A., Purnomo, T., dan Ambarwati, R. 2014. Pengembangan Enslikopedia dan LKS Invertebrata Laut untuk Pembelajaran Biologi. Jurnal BioEdu Berkala IImiah Pendidikan Biologi. 3(3): 580-588.

Hidayat, A., Saputro, S., dan Sukardjo, J.S. (2015). Pengembangan Media Pembelajaran Ensiklopedia Hukum-Hukum Dasar Kimia untuk Pembelajaran Kimia Kelas X SMAN 1 Boyolali dan SMAN 1 Teras. Jurnal Pendidika Kimia(JPK). 4(2): 47-56.

Indriati, G. 2014. Etnobotani Tumbuhan Obat yang digunakan Suku Anak Dalam di Desa Tabun Kecamatan VII Koto Kabupaten Tebo. Jurnal Saintek. VI(1): 52-56.

Lee, W.W. and Owens, D.L. (2004). Multimedia-Based Instructional Design. United States of America.

Mabel, Y., Simbala, H., dan koneri, R. 2016. Identifikasi dan Pemanfaatan Tumbuhan Obat Suku dani di kabupaten Jayawijaya Papua. Jurnal MIPA Unsrat Online. 5(2): 103-107.

Nizar, S., Ulung, Y.A., dan Susanti, R. (2017).Pengembangan Ensiklopedia Tanaman Obat Koleksi PT. Sidomuncul sebagai Media Pembelajaran Materi Plantae Kelas X SMA. Journal of Biology Education. 6(1): 11-18.

Wati, E.R. (2016). Ragam Media Pembelajaran. Jakarta: Kata Pena.

Wijarini, F., dan Zulfadli. 2018. Desain Pengembangan Ensiklopedia Tumbuhan Obat Berbasis Potensi Lokal Di kota Tarakan. Jurnal Inovasi Pendidikan Sains. 9(1): 11-16.

Yelianti, U., Kusuma, L., \& Intan, A. (2020). Pengembangan Booklet Tumbuhan Paku di Taman Hutan Raya Sultan Thaha Syaifuddin Sebagai Bahan Pengayaan Mata Kuliah Taksonomi Tumbuhan: The Development of Booklet on the Subject Matter of Ferns (Pteridophytes) from the Sultan Thaha Syaifuddin's Forest Park as Enrichment Material of Plant Taxonomy Course. BIODIK, 6(1), 58-75. https://doi.org/10.22437/bio.v6i1.8642 